
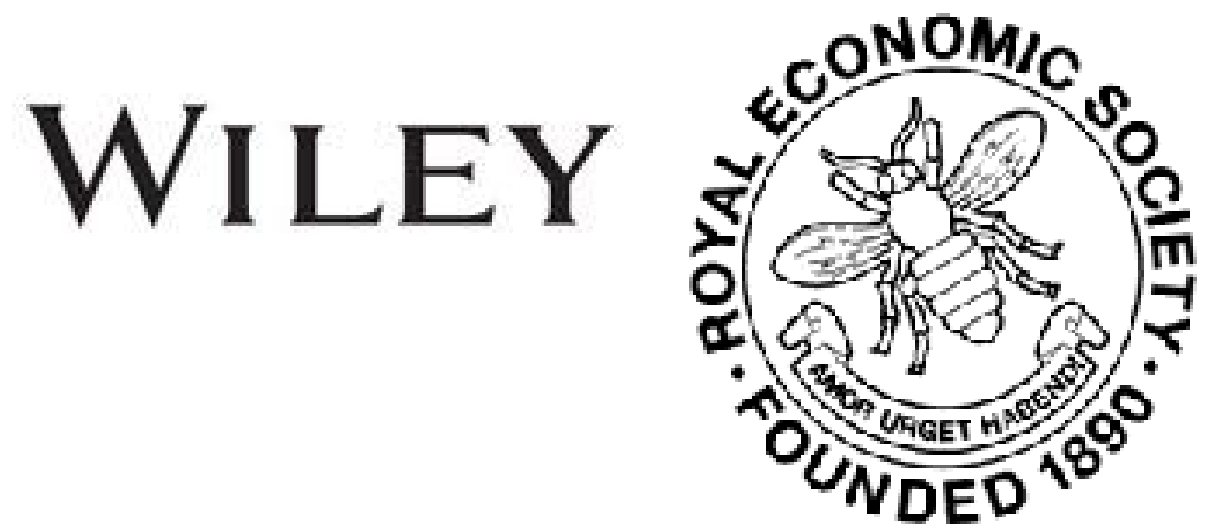

Trade Unions in the Tinplate Industry

Author(s): J. H. Jones

Source: The Economic Journal, Vol. 19, No. 74 (Jun., 1909), pp. 299-305

Published by: Wiley on behalf of the Royal Economic Society

Stable URL: http://www.jstor.org/stable/2221459

Accessed: 27-06-2016 02:59 UTC

Your use of the JSTOR archive indicates your acceptance of the Terms \& Conditions of Use, available at

http://about.jstor.org/terms

JSTOR is a not-for-profit service that helps scholars, researchers, and students discover, use, and build upon a wide range of content in a trusted digital archive. We use information technology and tools to increase productivity and facilitate new forms of scholarship. For more information about JSTOR, please contact support@jstor.org.

Wiley, Royal Economic Society are collaborating with JSTOR to digitize, preserve and extend access to The Economic Journal 
amounts as nearly as possible approximating to profits, and should not be influenced by other considerations. Such a body, if well chosen, might, we think, do really useful work, and would be available as a committee of reference, and it is an inquiry by a committee of this nature which we venture to suggest to your favourable consideration. ${ }^{1}$

\section{Trade Unions in the Tinplate IndUstry.}

THE changes that have occurred in the structure of labour associations in the tinplate industry during the past ten years are of great interest to the economist. The British industry, which is practically confined to South Wales and Monmouthshire, grew into importance during the period 1860-75. At that time a tinplate was a thin sheet of iron coated with tin; and the iron forge, the tinplate rolling mill, and the finishing department (or tinhouse) formed one factory. The rates of wages paid the men were determined partly by the custom of the district and partly by individual bargaining. The first association of workers of which we have evidence was formed in 1871 (during a period of rapid expansion of trade) and was confined to the western division, while it consisted of workers in all three departments. Uniform wage rates were granted in 1874. There is no evidence of a continuous association before 1887 , but there appear to have been a number of temporary combinations.

Between 1883 and 1886 steel superseded iron as the raw material in the manufacture of tinplates, and steel factories, in which tinplate bars were made, were generally distinct from tinplate factories. The employés in the two factories were not so closely connected as previously, and steel workers became members of an independent association. Thus it was by a change in the character of the product that the process of disintegration was started. In the winter of 1886-7 a strike took place in Monmouthshire, which resulted in the formation of the South Wales, Monmouthshire and Gloucestershire Tinplate Makers' Associa-

1 In defending the proposal to tax the capital value of ungotten minerals the Chancellor of the Exchequer said, May 12, "If they could value ungotten minerals for the purposes of purchase, was it not absurd to say they could not be valued for the purposes of taxation?" After this it will not be said that they cannot be valued for the purposes of allowance of depreciation, or fall in value, due to their gradual reduction by sale in computing taxable profits. The Income Tax Acts tax profits only. It is the hopelessly antiquated scheme of administration, formulated in the middle of last century under such different conditions of commerce, which is still used to compute those profits, and ill fits the needs of to-day. - Note by $\mathrm{Mr}$. Leake. 
tion, the first to include the eastern division. This Society, which remained in existence twelve years, included millmen and tinhousemen. It was merely a wage-protective association, and its energies were chiefly directed to-

1. Maintaining the " 1874 list."

2. Preventing the introduction of new machinery.

3. Restricting the output.

Until the McKinley Tariff Act was passed in 1890, the United States were the largest buyers of tinplates from South Wales. The loss of the American market resulted in severe depression for about six years, and in a change in the character of the product. The trade in blackplate (i.e., untinned sheets) and sheet steel was developed. This trade did not create a demand for labour in the tinhouse, so the workers in this department attempted to prevent the manufacture of such plate.

Another result of the depression was the introduction of new labour-displacing machinery into the tinhouse. There was consequently a clear division of interests between millmen and tinhousemen, and this undoubtedly led to the collapse of the union in 1898. Tinhousemen complained that millmen were slack in their contributions; the latter replied that they were too often involved in disputes which affected the tinhouse only. The necessity of independent associations was clear to all.

It must be acknowledged that the Society was a comparative failure. For the first four years the 1874 list was maintained without difficulty, but during the depression that followed there was no uniformity. In 1895 and 1896, after hard struggles, the list was recovered; but immediately after the victories a large proportion of the men ceased to contribute, and the union thus lost its power to resist demands for reductions in individual works. Further, the Masters' Association, which had been re-established in the same year as the men's Society was formed, was disbanded in 1896 . Probably the failure of this association is partly accounted for by the fact that the workmen's union was weak. Agreements could not be enforced, and consequently the non-associated employer enjoyed an advantage. A condition of success of an employers' association is the existence of a workmen's society strong enough to force the non-associated employer to pay rates at least as high as those agreed upon by the two executives.

After the Masters' Association had been disbanded many of the employers ignored the union secretary and his executive and made agreements with the men under their control. This further 
weakened the union, and by the autumn of the following year concessions had been made at so many of the works that a resolution was passed at the October Council meeting of the Society submitting to a general reduction of not more than 15 per cent. This so incensed the section which had been most loyal-Briton Ferry-that they decided to sever connection with the Society for an indefinite period. This proved to be the death-blow, and by the end of the year the Society had ceased to exist.

The causes of failure may be briefly given :-

1. Undoubtedly the chief cause was the lack of identity of interests of millmen and tinhousemen. The trade in black plate and sheet steel benefited only the millmen, who thus recovered from the loss of the American market long before operatives in the tinhouse did. Moreover, new machinery in the tinhouse, by diminishing cost of production, increased slightly the demand for labour in the mills. This, however, was poor consolation to the displaced tinhousemen.

2. The Society was merely a wage-protective association, and there were no means of punishing those who refused to contribute. Men often joined the union shortly before a dispute and left immediately after the settlement.

3. The executive lost the confidence of the men by bad administration of the funds.

4. Some employers were unduly favoured by the men's officials, who were therefore mistrusted by the majority.

At the end of 1898 the men were unorganised, and the majority of them working at reduced rates. It was evident to all that the millmen and tinhousemen would not combine to form a new association. The majority of the latter joined the Dockers' Union, and the rest threw in their lot with the gasworkers. The millmen were divided among themselves. One section decided to join the Steel Smelters' Association, in which society they ultimately formed a self-governing body, enjoying their own District Council, which decided all questions affecting millmen. The resolutions of the District Council could, however, be vetoed by the Central Executive, and on this committee their representatives were in a minority.

The other section decided to form an independent societythe Tin and Sheet Millmen's Association. The members of this society were of opinion that to become the weaker section of a strong union would not be wise policy. Further they felt that least of all could they join the Steel Smelters' Association, as the interests of the two bodies were directly opposed. Dumping of

No. 74.- -vol. xIX. 
tinplate bars on an extensive scale, whilst benefiting the tinplate industry, would injure the steel worker. It was quite possible, they contended, that the steel smelters might seek their co-opera. tion in an attempt to prevent dumping.

It is sometimes argued that if there are more than one society in a trade, the power of the central authority is weakened-too rigid an exercise of authority, we are told, will send the recalcitrants into the rival union. The experience of the two millmen's societies does not support this contention. It is probably nearer the truth to say that one society would not willingly take over the discontented members of the other unions, as discipline would be weakened. Societies, as a rule, do not care to have members who are easily dissatisfied : the strength of a union does not lie in numbers only. The policy of the Steel Smelters' Association up to 1899 is partly explained by this fact. For four years members of the old Tinplaters' Society had been clamouring for admission into the larger society, but they were steadily refused.

At the beginning of 1899 pieceworkers in the tinplate industry were members of one of four unions. Trade had improved rapidly: new markets had been sought and discovered. Everyone wanted uniform wage rates, and above all things employers desired to be free from disputes. Not only was there a larger percentage of unionists in the trade than ever before, but their leaders were also likely to enjoy the confidence of the employers. A new Masters' Association was formed in April, and the time was ripe for the establishment of a Conciliation Board. In June the first joint conference was held, and this resulted in the formation of a Conciliation Board, which is still in existence. An unpromising start was made, because, although the 1874 list was recovered, there was complete lack of understanding among the representatives of the men. Naturally the chief function of the Board is to make the annual wages agreement. The Conciliation Board possesses no written constitution, nor is there a uniform method of choosing the men's representatives. Probably its procedure is at this stage largely determined by custom or precedent. Many of the characteristics of such boards are prominent; e.g., the representatives of the men attend the meetings with full power to settle disputes and make agreements; the claims brought forward are generally greater than the concessions expected, leaving a " margin for conciliation."

In the early days claims were submitted by each society to the Board, and they were there discussed for the first time; in other 
words, there was no previous conference of the representatives of the four workers' associations. This was the most serious defect at that time, and the weakness of the position soon became evident. Consequently, a conference of the workmen's representatives was called in June, 1901, and the outcome of this meeting was the establishment of the "Tinplate and Sheet Mill Workers' Wages and Disputes Board."

This board consisted of three representatives from each of the four affiliated societies. The demands of the various unions, which had previously been submitted to the Concilation Board, were now discussed by the Disputes Board, and submitted by this committee to the joint conference. "In any grievance arising out of any department connected with the trade, no one society affiliated shall be allowed to hand in notices or stop work before first submitting such grievance for the consideration of the Board." On all important questions any society had the right to demand a vote of the members of all the affiliated societies.

For a short time only did the new method give satisfaction. The personal relations of the leaders was a serious handicap. Very early, too, it was found necessary to appoint sectional subcommittees to investigate matters involving a knowledge of technical detail.

A subject of endless dispute between millmen and employers was the method of remunerating workers employed on a certain task-the manufacture of plates known as Canadas and doubles. It formed the main topic of discussion at several meetings of the Conciliation Board. On more than one occasion the masters suggested arbitration, but this the millmen strenuously opposed. Ultimately, in spite of the wishes of the millmen (who were in a position to fight), the Wages and Disputes Board, by the casting vote of the chairman (who represented the workers in the finishing department), decided to submit the case to arbitration. A victory to the employers left the millmen very dissatisfied with the Disputes Committee. Again, a few months later a resolution was passed by the Disputes Board, recommending the affiliated societies to combine to fight the employers in court on a question of custom. This the societies refused to do, and the Steel Smelters' Association fought and won without assistance. The policy of the unions representing the finishing department so angered the millmen that the District Council of the S.S.A. resolved (in July, 1904) to withdraw from the Disputes Board. The Tin and Sheet Millmen's Society followed a few months later, and the Board ceased to exist. 
The causes of the failure of the Wages and Disputes Board are :-

1. Voting power did not vary with interest.

Millmen did not decide mill questions, but were sometimes outvoted on them by tinhousemen. The representatives of the former body complained that they did not have sufficient control in their hands.

2. Millmen were on many occasions called together to discuss matters in which they were not directly interested. This meant considerable expense and a great waste of time. The secretary of one of the unions writes in his report:- "There is no denying the fact that much of the time of the millmen's representatives has been taken up in the past, discussing questions that did not in the least affect them, and often blunders were committed because the men taking part in the debate did not understand the real grievance under discussion."

Recent changes can only be very briefly indicated.

With the collapse of the Disputes Committee, a new method was adopted. The two sections met the employers independently, but the associations within each section acted jointly-e.g., millmen's demands were discussed by a joint meeting of the S.S.A. and the T. \& S.M.A.

The employers then found that two meetings (instead of one) were too expensive and wasted too much time, so that this summer all met in the same conference. The board in its present form differs from the old board in that the discussion of claims put forward by one department is carried on by representatives of that department. All the representatives retire together, but the deliberations are sectional. Since sectional wage agreements have been the rule, the condition has been inserted "that any settlement as to wages and conditions arranged for the ensuing year will only be operative from the date upon which an arrangement is completed with any other section of the trade."

All that has been written refers to pieceworkers. Artisans who were members of the Artisans' Union, Engineers' Union, or the Gasworkers' Union were not included in the annual wage agreements. In 1902, shortly after wages had been fixed for the ensuing year, thirty boiler-firemen in the Llanelly district, members of the Gasworkers' Union, handed in notices with a demand for an eight hours' day. Thus a serious defect in the method of settlement became apparent. To prevent a possible repetition, the following rule was made :- "If any dispute arises in cases of employés not included in the wage agreement, a committee of 
three masters and three men shall discuss the matter, and failing to agree, the matter shall be reported to the Conciliation Board for settlement. All disputes shall be settled within a reasonable time."

The Artisans' Union, which includes a large majority of the day workmen in the industry, was established in 1889. For nine years it remained outside the Conciliation Board, and consequently was able to render futile much of the work of that Board. It occupied a very strong position, and the secretary generally succeeded in obtaining the demands by direct negotiation with the executive of the Employers' Association.

This year has witnessed a change. The last joint conference was attended by the representatives of the Artisans' and Engineers' Associations, and the annual wage agreements, although sectional in character, are signed by the leaders of the six affiliated societies.

\section{J. H. JONES}

\section{The Incidence of Import DUties-A Correction and Explanation.}

IT will be apparent to anybody who has read my note in the last issue of this JodRNAL that I counted the revenue derived from the import duty twice over. Throughout the article " the proceeds of the tax" should have been written for "twice the proceeds of the tax," and "T" for " $2 \mathrm{~T}$." The blunder is of the kind which simply cannot be explained; I can only suppose that, as I was thinking chiefly of the effects of increasing and decreasing returns on the incidence of protective import duties, I never properly realised what was implied in the results incorrectly reached by a mechanical argument relating to the case in which neither increasing nor decreasing returns ruled. I may seize this opportunity to point out that in the abstract cases with which I dealt the formula for the effect of an export duty is the same as that for the effect of an import duty, and that the gain or loss derived from an export duty on $B$, which yielded the same revenue as a given import duty on $\mathrm{A}$, would be the same as the gain or loss derived from the import duty on A. The proof is furnished in the note beneath. ${ }^{1}$ The sole difference consists in

1 Let the two countries, $P$ (the taxing country) and $Q$, produce both $A$ and $B$ before and after the imposition by $\mathrm{P}$ of either the import duty or the export duty supposed. Let values in $\mathrm{P}$ be measured in some unit of constant value. Suppose that imports of $\mathrm{A}$ would contract to $i$, and exports of $\mathrm{B}$ to $e$, if $\mathrm{P}$ imposed an import duty $t$ on A. Suppose, further, that exports of $B$ would be reduced to $e^{\prime}$ and 